\title{
Acetobacter senegalensis sp. nov., a thermotolerant acetic acid bacterium isolated in Senegal (sub-Saharan Africa) from mango fruit (Mangifera indica L.)
}

Correspondence

Bassirou Ndoye

ndoye.b@fsagx.ac.be
Bassirou Ndoye, ${ }^{1,2}$ Ilse Cleenwerck, ${ }^{3}$ Katrien Engelbeen, ${ }^{3}$ Robin Dubois-Dauphin, ${ }^{1}$ Amadou Tidiane Guiro, ${ }^{2}$ Stefanie Van Trappen, ${ }^{3}$ Anne Willems ${ }^{4}$ and Phillipe Thonart ${ }^{1,5}$

${ }^{1}$ Faculté Universitaire des Sciences Agronomiques de Gembloux, Unité de Bio-industries, 2, Passage des Déportés, B-5030 Gembloux, Belgium

${ }^{2}$ Institut de Technologie Alimentaire de Dakar, Route des Pères Maristes, BP 2765, Dakar, Sénégal

${ }^{3}$ BCCM/LMG Bacteria Collection, Faculty of Sciences, Ghent University, K. L. Ledeganckstraat 35, B-9000 Ghent, Belgium

${ }^{4}$ Laboratory of Microbiology, Faculty of Sciences, Ghent University, K. L. Ledeganckstraat 35, B-9000 Ghent, Belgium

${ }^{5}$ Centre Wallon de Biologie Industrielle, Service de Technologie Microbienne, Université de Liège, B-40, Sart-Tilman, 4000 Liège, Belgium
The taxonomy of acetic acid bacteria (AAB) has substantially changed in recent years. According to De Ley et al. (1984), AAB were classified in the family Acetobacteraceae in two genera, Acetobacter and Gluconobacter. At the time

\section{Abbreviation: $A A B$, acetic acid bacteria}

The GenBank/EMBL/DDBJ accession number for the 16S rRNA gene sequence of CWBI-B418 ${ }^{\top}$ is $A Y 883036$.

A table comparing the oxidation of carbon sources by strain CWBI$\mathrm{B} 418^{\top}$ and Acetobacter tropicalis is available with the online version of this paper. of writing, $\mathrm{AAB}$ are classified in nine genera, namely Acetobacter, Gluconobacter, Acidomonas, Gluconoacetobacter, Asaia, Kozakia, Saccharibacter, Swaminathania and Neoasaia in the family Acetobacteraceae, class Alphaproteobacteria (Cleenwerck et al., 2002; Loganathan \& Nair, 2004; Jojima et al., 2004; Yukphan et al., 2005). AAB are widespread in nature and are generally capable of oxidizing ethanol to acetic acid. This enables them to grow in wine, cider, sake and kombucha tea, resulting in their use for the production of different kinds of vinegar and beverages (Trček \& Teuber, 2002). In tropical areas such as sub-Saharan Africa, where the ambient temperature is regularly above $30^{\circ} \mathrm{C}$, industrial 
vinegar production is almost exclusively performed by using thermotolerant $\mathrm{AAB}$, as they considerably reduce the costs associated with the use of cooling water, which otherwise rapidly become prohibitive (Sow et al., 2005; Ndoye et al., 2006).

Two Acetobacter strains, Acetobacter sp. CWBI-B $418^{\mathrm{T}}$ and Acetobacter pasteurianus CWBI-B419, were recently isolated from mango fruit (Mangifera indica) in Senegal and 'Dolo' (local beer obtained by fermenting cereal products) in Burkina Faso, respectively. These strains were selected as potential strains for vinegar production in sub-Saharan Africa on the basis of their ability to grow and produce acetic acid at higher temperatures (Ndoye et al., 2006). The two strains were used in a study of artisanal production of spirit vinegar of $6 \%$ via the Orleans method (unpublished data) and were evaluated as freeze-dried starters in an acetification process (Ndoye et al., 2007). The present study deals with the determination of the taxonomic position of strain CWBI-B $418^{\mathrm{T}}$ in the genus Acetobacter. The polyphasic characterization of the novel strain by means of genotypic and phenotypic methods falls within the framework of a project on sustainable and durable natural resource management and valorization in Senegal and Burkina Faso. Based on the results obtained, we conclude that strain CWBI$\mathrm{B} 418^{\mathrm{T}}$ represents a novel species of the genus Acetobacter.

Acetobacter reference strains used in this study were obtained from the BCCM/LMG Bacteria Collection (http:// bccm.belspo.be). Reference strains were grown according to the supplier's specifications, unless indicated otherwise. Strain CWBI-B418 ${ }^{\mathrm{T}}$ was cultivated on medium 13 agar from the BCCM/LMG Catalogue of Cultures (http://bccm. belspo.be/db/; $2.5 \%$ D-mannitol, $0.5 \%$ yeast extract, $0.3 \%$ peptone, $1.5 \%$ agar) by incubation at $28{ }^{\circ} \mathrm{C}$ under aerobic conditions for 1-3 days and then checked for purity. The strain grew well on this medium at $28{ }^{\circ} \mathrm{C}$ and appeared as visible, opaque, beige colonies within 1 day of incubation. Small colony variations were noted, with some colonies being smooth and others slimy, irregular and spreading. Previous studies showed that the strain exhibited good growth between 25 and $40{ }^{\circ} \mathrm{C}$, with optimal growth at $35^{\circ} \mathrm{C}$ on YGM medium (1\% yeast extract, $2 \%$ glucose, $2 \%$ D-mannitol, with $2.5 \%$ ethanol and $0.5 \%$ acetic acid added aseptically after sterilization), but slow growth at $42{ }^{\circ} \mathrm{C}$ (Ndoye et al., 2006).

Cell morphological characteristics, including shape and size, were determined from cells grown at $28^{\circ} \mathrm{C}$ for 1 day on medium 13 under aerobic conditions. Gram staining was carried out according to the method of Hucker \& Conn (1923). Cells of strain CWBI-B418 ${ }^{\mathrm{T}}$ were Gram-negative, non-spore-forming coccoids, approximately $0.8 \mu \mathrm{m}$ in width and $1.2-2 \mu \mathrm{m}$ in length. Cells occurred singly, in pairs or in short chains and occasionally in long chains.

Conventional biochemical tests were performed according to standard methods (De Ley et al., 1984). Oxidase activity was tested by using $1 \% N, N, N^{\prime}, N^{\prime}$-tetramethyl p-phenylenediamine. Catalase activity was tested by adding young cells to a drop of a $10 \% \mathrm{H}_{2} \mathrm{O}_{2}$ solution and observing production of $\mathrm{O}_{2}$. Strain CWBI-B418 ${ }^{\mathrm{T}}$ was oxidase-negative and catalase-positive. It was able to oxidize ethanol to acetic acid and acetate and lactate to $\mathrm{CO}_{2}$ and $\mathrm{H}_{2} \mathrm{O}$, two biochemical properties typical of AAB.

The phylogenetic affiliation of strain CWBI-B418 ${ }^{\mathrm{T}}$ was previously determined by Ndoye et al. (2006) based on $16 \mathrm{~S}$ rRNA gene sequence analysis, where it was shown that it belonged to the genus Acetobacter. Previous studies (Lisdiyanti et al., 2001; Cleenwerck et al., 2002) showed the existence of two stable sublineages in the genus Acetobacter. In the present study a new phylogenetic tree was constructed based on the neighbour-joining method (Saitou \& Nei, 1987) (Fig. 1) using the BioNumerics 4.5 software package (Applied Maths). Unknown bases were discarded from the calculations. Bootstrapping analysis (Felsenstein, 1985) was undertaken to test the statistical reliability of the topology of the neighbour-joining tree by using 1000 bootstrap resamplings of the data. Fig. 1 shows that strain CWBI$\mathrm{B} 418^{\mathrm{T}}$ belonged to the stable subcluster containing Acetobacter oeni, A. estunensis, A. nitrogenifigens, A. aceti, A. tropicalis, A. cerevisiae, A. orleanensis, A. malorum, A. orientalis, A. cibinongensis and A. indonesiensis. $16 \mathrm{~S}$ rRNA gene sequence similarities obtained by pairwise alignment with the BioNumerics 4.5 software package between strain CWBI-B $418^{\mathrm{T}}$ and the type strains of recognized Acetobacter species were $99.3 \%$ for A. tropicalis, $98.7 \%$ for $A$. indonesiensis, $98.5 \%$ for A. cibinongensis, $98.4 \%$ for $A$. cerevisiae, $98.4 \%$ for A. orientalis, $98.3 \%$ for A. malorum, $98.1 \%$ for A. oeni, $98.1 \%$ for A. orleanensis, $98.0 \%$ for $A$. syzygii, $98.0 \%$ for A. estunensis, $98.0 \%$ for A. pomorum, $97.9 \%$ for $A$. aceti, $97.8 \%$ for A. lovaniensis, $97.7 \%$ for $A$. pasteurianus, $97.5 \%$ for $A$. nitrogenifigens and $97.5 \%$ for $A$. peroxydans.

Strain CWBI-B4 $18^{\mathrm{T}}$ was hybridized to all phylogenetically related recognized Acetobacter species to determine whether it belonged to one of these species. DNA for DNA-DNA hybridizations and DNA base composition analysis was prepared according to the method of Wilson (1987) with minor modifications (Cleenwerck et al., 2002). DNA-DNA hybridizations were performed by using a modification of the microplate method described by Ezaki et al. (1989) (Goris et al., 1998; Cleenwerck et al., 2002). The hybridization temperature was $46^{\circ} \mathrm{C}$. Reciprocal reactions (e.g. $\mathrm{A} \times \mathrm{B}$ and $\mathrm{B} \times \mathrm{A}$ ) were performed and the variation between them was within the limits of the method, of which the mean standard deviation is $\pm 7 \%$ (Goris et al., 1998). The DNA relatedness percentages presented are the mean of a minimum of four hybridization experiments, including the reciprocal reactions. Strain CWBI-B418 ${ }^{\mathrm{T}}$ showed an intermediate level of DNA-DNA relatedness with A. tropicalis LMG $19825^{\mathrm{T}}$ (52\%), and low levels with A. estunensis LMG $1626^{\mathrm{T}}(9 \%)$, A. oeni LMG $21952^{\mathrm{T}}(6 \%)$, A. aceti LMG $1504^{\mathrm{T}}$ (7\%), A. cerevisiae LMG $1625^{\mathrm{T}}$ (18\%), A. orleanensis LMG $1583^{\mathrm{T}}$ (22\%), A. malorum LMG $1746^{\mathrm{T}}(18 \%)$, A. orientalis 


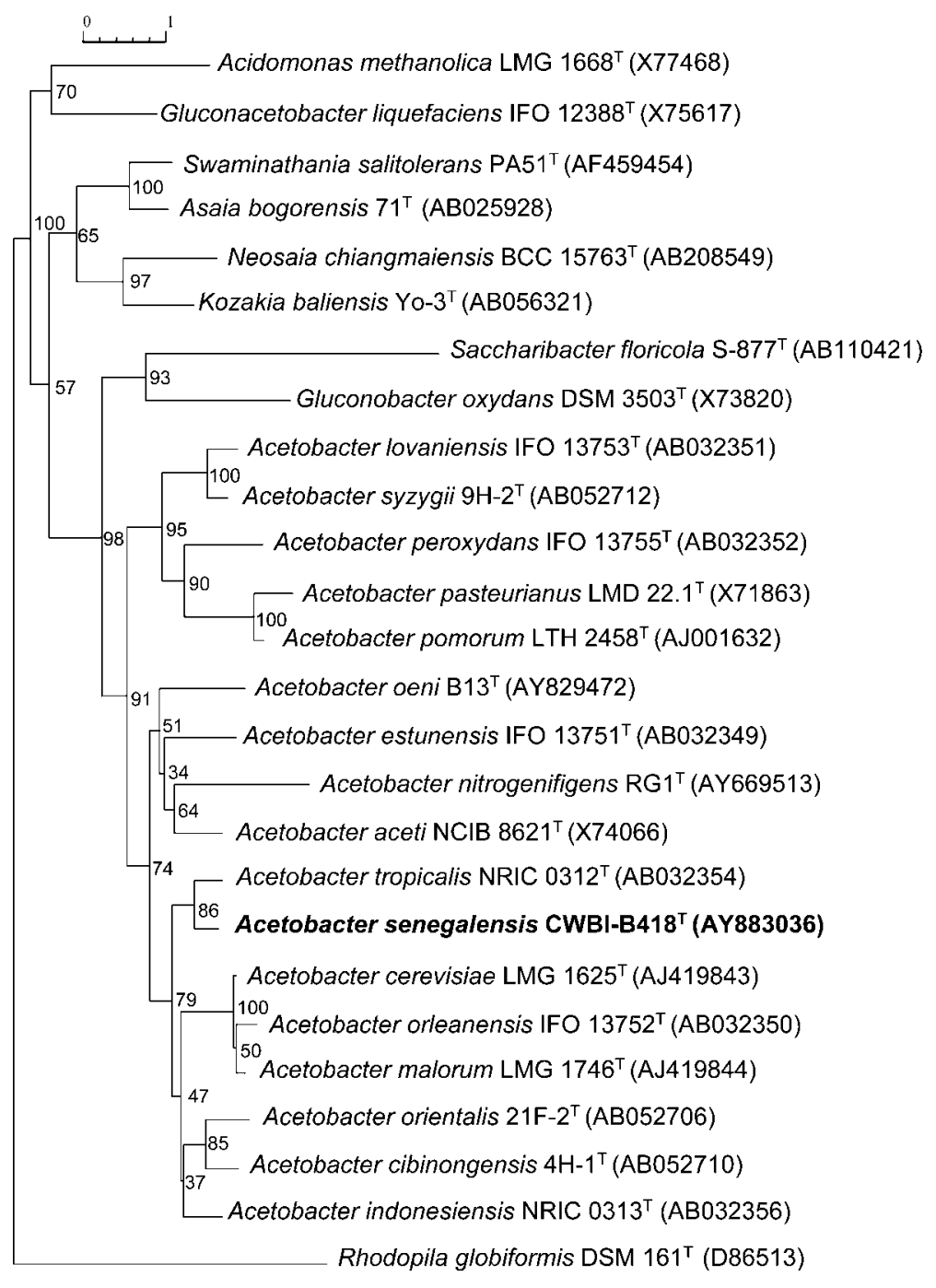

Fig. 1. Neighbour-joining tree based on nearly complete $16 \mathrm{~S}$ rRNA gene sequences of strain CWBI-B418 ${ }^{\top}$ and related species of the family Acetobacteraceae. The significance of each branch is indicated by a bootstrap value calculated based on 1000 subsets. Bar, $1 \mathrm{nt}$ substitution per $100 \mathrm{nt}$.

LMG $21417^{\mathrm{T}}$ (15\%), A. cibinongensis LMG $21418^{\mathrm{T}}(17 \%)$, A. indonesiensis LMG $19824^{\mathrm{T}}(21 \%)$ and A. nitrogenifigens LMG $23498^{\mathrm{T}}(3 \%)$. As these values are clearly below $70 \%$, the generally accepted limit for species delineation (Wayne et al., 1987; Stackebrandt et al., 2002), the results indicate that strain CWBI-B418 ${ }^{\mathrm{T}}$ represents a novel genospecies within the genus Acetobacter. The DNA base composition of strain CWBI-B418 ${ }^{\mathrm{T}}$ was determined by HPLC according to the method of Mesbah et al. (1989). Non-methylated phage $\lambda$ DNA (Sigma) was used as a calibration reference. The DNA G + C content of strain CWBI-B $418^{\mathrm{T}}$ was $56.0 \mathrm{~mol} \%$. This value is consistent with those of recognized members of the genus Acetobacter (Lisdiyanti et al., 2000, 2001; Cleenwerck et al., 2002; Silva et al., 2006).

To confirm finally whether strain CWBI-B $418^{\mathrm{T}}$ represented a novel Acetobacter species, phenotypic characteristics that enable it to be differentiated from recognized Acetobacter species were examined as described by Cleenwerck et al. (2002). Strain CWBI-B $418^{\mathrm{T}}$ could be differentiated from most species of the genus Acetobacter by its ability to grow on yeast extract with $30 \% \mathrm{D}$-glucose, the ability to grow with ammonium as sole nitrogen source with ethanol as carbon source and the ability to grow in the presence of $10 \%$ ethanol (Table 1). Strain CWBI-B418 ${ }^{\mathrm{T}}$ differed from $A$. tropicalis, its phylogenetically closest neighbour, by the ability to grow in ammonium with ethanol, the ability to grow in $10 \%$ ethanol, the ability to grow on yeast extract with $30 \%$ D-glucose and the inability to grow on maltose.

Additional characteristics differentiating strain CWBI$\mathrm{B} 418^{\mathrm{T}}$ from $A$. tropicalis were determined by using API $50 \mathrm{CH}$ strips (bioMérieux), following the manufacturer's guidelines for oxidation. The bacterial suspensions were made up in API 50CHL medium, except that bromocresol purple was substituted by bromocresol green $\left(0.17 \mathrm{~g} \mathrm{l}^{-1}\right)$. The colour change in the cup was read after 1, 2 and 3 days incubation at $30{ }^{\circ} \mathrm{C}$. The results obtained indicated that strain CWBI-B $418^{\mathrm{T}}$ differed from $A$. tropicalis by the ability to produce acid from D-glucose and D-xylose aerobically (see Supplementary Table S1 in IJSEM Online).

The results presented above allow the genotypic and phenotypic differentiation of strain CWBI-B $418^{\mathrm{T}}$ from all 
Table 1. Differential characteristics between strain CWBI-B418 ${ }^{\top}$ and related Acetobacter species

Taxa: 1, A. cerevisiae (four strains); 2, A. malorum LMG $1746^{\mathrm{T}}$; 3, A. pasteurianus (seven strains); 4, A. pomorum LMG $18848^{\mathrm{T}}$; 5, A. peroxydans (two strains); 6, A. lovaniensis LMG $1617^{\mathrm{T}} ; 7$, A. orleanensis (four strains); 8, A. indonesiensis (two strains); 9, A. tropicalis (two strains); 10, A. estunensis (three strains); 11, A. aceti (four strains); 12, A. syzygii LMG 21419 ${ }^{\mathrm{T}}$; 13. A. cibinongensis LMG $21418^{\mathrm{T}} ; 14$, A. orientalis LMG $21417^{\mathrm{T}} ; 15$, A. oeni $\mathrm{B}^{\mathrm{T}} \mathrm{T}^{\mathrm{T}} ; 16$, A. nitrogenifigens $\mathrm{RG}^{\mathrm{T}} ; 17$, strain CWBI-B418 ${ }^{\mathrm{T}}$. + , Positive; - , negative; $\mathrm{W}$, weakly positive; $\mathrm{V}$, variable; ND, not determined. Data for taxa 1-11 were taken from Cleenwerck et al. (2002), data for taxa 12-15 were taken from Silva et al. (2006) and data for taxon 16 were taken from Dutta \& Gachhui (2006), except where indicated otherwise.

\begin{tabular}{|c|c|c|c|c|c|c|c|c|c|c|c|c|c|c|c|c|c|}
\hline Characteristic & 1 & 2 & 3 & 4 & 5 & 6 & 7 & 8 & 9 & 10 & 11 & 12 & 13 & 14 & 15 & 16 & 17 \\
\hline \multicolumn{18}{|l|}{ Formation from D-glucose: } \\
\hline 5-Keto-D-gluconic acid & - & - & - & - & - & - & - & - & - & - & + & - & - & - & + & ND & - \\
\hline 2-Keto-D-gluconic acid & + & + & $\mathrm{V}$ & - & - & + & + & + & + & + & + & - & + & + & - & $\mathrm{ND}$ & + \\
\hline $\begin{array}{l}\text { Growth in ammonium with } \\
\text { ethanol }\end{array}$ & - & - & - & - & + & + & - & - & - & + & + & - & $\mathrm{W}$ & - & - & + & + \\
\hline \multicolumn{18}{|l|}{ Growth on carbon sources: } \\
\hline Glycerol & + & + & $\mathrm{V}$ & + & - & + & + & + & + & $\mathrm{V}$ & + & + & + & + & + & + & + \\
\hline Maltose & - & - & $\mathrm{V}$ & - & + & - & $\mathrm{V}$ & + & + & - & $\mathrm{V}$ & + & - & $\mathrm{W}$ & - & + & - \\
\hline Methanol & - & + & - & - & - & + & - & - & - & - & - & - & - & $\mathrm{w}$ & - & - & - \\
\hline Growth in $10 \%$ ethanol & $\mathrm{ND}$ & $+^{*}$ & $+\dagger$ & $-\dagger$ & $-\dagger$ & $-\dagger$ & $-\dagger$ & $-\dagger$ & $-\dagger$ & $-\dagger$ & $-\dagger$ & $-\dagger$ & $-\dagger$ & $-\dagger$ & $+\dagger$ & + & + \\
\hline $\begin{array}{l}\text { Growth on yeast extract } \\
+30 \% \text { D-glucose }\end{array}$ & - & + & $\mathrm{V}$ & - & - & - & - & - & - & - & - & - & + & - & - & + & + \\
\hline Catalase & + & + & + & + & - & + & + & + & + & + & + & + & + & + & + & & + \\
\hline Motility & - & - & $\mathrm{v} \dagger$ & $-\ddagger$ & $+\dagger$ & $\begin{array}{c}\mathrm{v}(\text { mostly } \\
+) \dagger\end{array}$ & $\mathrm{v} \dagger$ & $\mathrm{v} \dagger$ & $\mathrm{v}^{\dagger}$ & $+\dagger$ & $\mathrm{v} \dagger$ & $+\dagger$ & $-\dagger$ & $\begin{array}{c}\mathrm{V}(\text { mostly } \\
+) \dagger\end{array}$ & + & + & + \\
\hline $\begin{array}{l}\text { DNA G }+ \text { C content } \\
(\mathrm{mol} \%)\end{array}$ & $56.0-57.6$ & 57.2 & $53.2-54.3$ & 52.1 & $59.7-60.7$ & $57.1-58.9$ & $55.7-58.1$ & $54.0-54.2$ & $55.6-56.2$ & $59.2-60.2$ & $56.9-58.3$ & $54.3-55.4 \dagger$ & $53.8-54.5 \dagger$ & $52.0-52.8 \dagger$ & 58.1 & 64.1 & 56.0 \\
\hline
\end{tabular}

${ }^{\star}$ Data obtained in this study.

$\dagger$ Data taken from Lisdiyanti et al. (2000, 2001).

$\ddagger$ Data taken from Sokollek et al. (1998). 
recognized Acetobacter species. Strain CWBI-B418 ${ }^{\mathrm{T}}$ should therefore be classified as representing a novel species of the genus Acetobacter, for which the name Acetobacter senegalensis sp. nov. is proposed.

\section{Description of Acetobacter senegalensis sp. nov.}

Acetobacter senegalensis (se.ne.gal.en'sis. N.L. m. adj. senegalensis referring to the country from where the type strain of this species was isolated).

Cells are Gram-negative, non-spore-forming, coccoid, approximately $0.8 \mu \mathrm{m}$ wide and $1.2-2 \mu \mathrm{m}$ long. Cells occur singly, in pairs or in short chains and occasionally in long chains. Oxidase-negative and catalase-positive. Strictly aerobic. Optimal growth temperature on YGM medium is $35^{\circ} \mathrm{C}$, but good growth is observed between 28 and $40^{\circ} \mathrm{C}$. On medium 13 agar, colonies appear within 1 day of incubation at $28^{\circ} \mathrm{C}$ and are circular, convex, opaque, beige and approximately $0.6 \mathrm{~mm}$ in diameter. Characterized by the combination of the following phenotypic features: able to grow on yeast extract with $30 \% \mathrm{D}-$ glucose, able to grow with ammonium as sole nitrogen source with ethanol as carbon source, able to grow in the presence of $10 \%$ ethanol, able to grow on glycerol as carbon source but not on maltose or methanol as carbon source, and produces 2-keto-D-gluconic acid from D-glucose, but not 5-keto-D-gluconic acid. The G $+\mathrm{C}$ content of the DNA is $56.0 \mathrm{~mol} \%$.

The type strain, CWBI-B418 ${ }^{\mathrm{T}}\left(=\mathrm{LMG} 23690^{\mathrm{T}}=\mathrm{DSM}\right.$ $18889^{\mathrm{T}}$ ), was isolated from mango fruit in Senegal (subSaharan Africa).

\section{Acknowledgements}

This research was supported by the partnership between Région Wallonne and Senegal (DRI Contract No. 27/11/2003-134-S). The BCCM/LMG Bacteria Collection is supported by the Federal Public Planning Service - Science Policy, Belgium. We gratefully acknowledge the International Foundation for Science (IFS), Sweden, for financial support to B. N. via a grant program (Grant No. E/3595-1) awarded to him.

\section{References}

Cleenwerck, I., Vandemeulebroecke, K., Janssens, D. \& Swings, J. (2002). Re-examination of the genus Acetobacter, with descriptions of Acetobacter cerevisiae sp. nov. and Acetobacter malorum sp. nov. Int J Syst Evol Microbiol 52, 1551-1558.

De Ley, J., Gillis, M. \& Swings, J. (1984). Bergey's Manual of Systematic Bacteriology, vol. 1, pp. 268-278. Edited by N. R. Krieg \& J. G. Holt. Baltimore: Williams \& Wilkins.

Dutta, D. \& Gachhui, R. (2006). Novel nitrogen-fixing Acetobacter nitrogenifigens sp. nov., isolated from Kombucha tea. Int J Syst Evol Microbiol 56, 1899-1903.

Ezaki, T., Yashimoto, T. \& Yabuuchi, E. (1989). Fluorometric deoxyribonucleic acid-deoxyribonucleic acid hybridization in microdilution wells as an alternative to membrane filter hybridization in which radioisotopes are used to determine genetic relatedness among bacterial strains. Int J Syst Bacteriol 39, 224-229.

Felsenstein, J. (1985). Confidence limits on phylogenies: an approach using the bootstrap. Evolution 39, 783-791.

Goris, J., Suzuki, K., De Vos, P., Nakase, T. \& Kersters, K. (1998). Evaluation of a microplate DNA-DNA hybridization method compared with the initial renaturation method. Can J Microbiol 44, 1148-1153.

Hucker, G. J. \& Conn, H. J. (1923). Methods of Gram staining. NYS Agric Exp Sta Tech Bull 93, 3-37.

Jojima, Y., Mihara, Y., Suzuki, S., Yokozeki, K., Yamanaka, S. \& Fudou, R. (2004). Saccharibacter floricola gen. nov., sp. nov., a novel osmophilic acetic acid bacterium isolated from pollen. Int J Syst Evol Microbiol 54, 2263-2267.

Lisdiyanti, P., Kawasaki, H., Seki, T., Yamada, Y., Uchimura, T. \& Komagata, K. (2000). Systematic study of the genus Acetobacter with descriptions of Acetobacter indonensiensis sp. nov., Acetobacter tropicalis sp. nov., Acetobacter orleanensis (Henneberg 1906) comb. nov., Acetobacter lovaniensis (Frateur 1950) comb. nov., and Acetobacter estunensis (Carr 1958) comb. nov. J Gen Appl Microbiol 46, 147-165.

Lisdiyanti, P., Kawasaki, H., Seki, T., Yamada, Y., Uchimura, T. \& Komagata, K. (2001). Identification of Acetobacter strains isolated from Indonesian sources, and proposals of Acetobacter syzygii sp. nov., Acetobacter cibinongensis sp. nov., and Acetobacter orientalis sp. nov. J Gen Appl Microbiol 47, 119-131.

Loganathan, P. \& Nair, S. (2004). Swaminathania salitorans gen. nov., sp. nov., a salt-tolerant, nitrogen-fixing and phosphate-solubilizing bacterium from wild rice (Porterisia coarctata Tateoka). Int J Syst Evol Microbiol 54, 1185-1190.

Mesbah, M., Premachandran, U. \& Whitman, W. B. (1989). Precise measurement of the $\mathrm{G}+\mathrm{C}$ content of deoxyribonucleic acid by highperformance liquid chromatography. Int J Syst Bacteriol 39, 159-167.

Ndoye, B., Lebecque, S., Dubois-Dauphin, R., Tounkara, L., Guiro, T.-A., Kere, C., Diawara, B. \& Thonart, P. (2006). Thermoresistant properties of acetic acid bacteria isolated from tropical products of Sub-Saharan Africa and destined to industrial vinegar. Enzyme Microb Technol 39, 916-923.

Ndoye, B., Weekers, F., Diawara, B., Guiro, A. T. \& Thonart, P. (2007). Survival and preservation after freeze-drying process of thermoresistant acetic acid bacteria (TAAB) isolated from tropical products of Subsaharan Africa. J Food Eng 79, 1374-1382.

Saitou, N. \& Nei, M. (1987). The neighbor-joining method: a new method for reconstructing phylogenetic trees. Mol Biol Evol 4, 406-425.

Silva, L. R., Cleenwerck, I., Rivas, R., Swings, J., Trujillo, M. E., Willems, A. \& Velázquez, E. (2006). Acetobacter oeni sp. nov., isolated from spoiled red wine. Int J Syst Evol Microbiol 56, 21-24.

Sokollek, S. J., Hertel, C. \& Hammes, W. P. (1998). Description of Acetobacter oboediens sp. nov. and Acetobacter pomorum sp. nov., two new species isolated from industrial vinegar fermentations. Int J Syst Bacteriol 48, 935-940.

Sow, N. M., Dubois-Dauphin, R., Roblain, D., Guiro, A. T. \& Thonart, Ph. (2005). Polyphasic identification of a new thermotolerant species of lactic acid bacteria isolated from chicken faeces. Afr J Biotechnol 4, 409-421.

Stackebrandt, E., Frederiksen, W., Garrity, G. M., Grimont, P. A. D., Kämpfer, P., Maiden, M. C. J., Nesme, X., Rosselló-Mora, R., Swings, J. \& other authors (2002). Report of the ad hoc committee for the re-evaluation of the species definition in bacteriology. Int J Syst Evol Microbiol 52, 1043-1047. 
Trček, J. \& Teuber, M. (2002). Genetic and restriction analysis of the 16S-23S rDNA internal transcribed spacer regions of the acetic acid bacteria. FEMS Microbiol Lett 208, 69-75.

Wayne, L. G., Brenner, D. J., Colwell, R. R., Grimont, P. A. D., Kandler, O., Krichevsky, M. I., Moore, L. H., Moore, W. E. C., Murray, R. G. E. \& other authors (1987). International Committee on Systematic Bacteriology. Report of the ad hoc committee on reconciliation of approaches to bacterial systematics. Int J Syst Bacteriol 37, 463-464.
Wilson, K. (1987). Preparation of genomic DNA from bacteria. In Current Protocols in Molecular Biology, pp. 2.4.1.-2.4.5. Edited by F. M. Ausubel, R. Brent, R. E. Kingston, D. D. Moore, J. G. Seidman, J. A. Smith \& K. Struhl. New York: Green Publishing \& WileyInterscience.

Yukphan, P., Malimas, T., Potacharoen, W., Tanasupawat, S., Tanticharoen, M. \& Yamada, Y. (2005). Neoasaia chiangmaiensis gen. nov., sp. nov., a novel osmotolerant acetic acid bacterium in the $\alpha$-Proteobacteria. J Gen Appl Microbiol 51, 301-311. 